\title{
The lighthouse at the end of the chromosome* [version 1;
}

\section{peer review: 3 approved]}

*Adapted from, "The Lighthouse at the End of the World" Jules Verne (1905)

\section{Yahya Benslimane1, Lea Harrington 1-3}

${ }^{1}$ Department of Molecular Biology, University of Montreal, Institute for Research in Immunology and Cancer, Montreal, Quebec, Canada

2Department of Biochemistry, University of Montreal, Institute for Research in Immunology and Cancer, Montreal, Quebec, Canada

${ }^{3}$ Department of Medicine, University of Montreal, Institute for Research in Immunology and Cancer, Montreal, Quebec, Canada

V1 First published: 11 Dec 2015, 4(F1000 Faculty Rev):1427

https://doi.org/10.12688/f1000research.6664.1

Latest published: 11 Dec 2015, 4(F1000 Faculty Rev):1427

https://doi.org/10.12688/f1000research.6664.1

\section{Abstract}

Fluorescence microscopy can be used to assess the dynamic localization and intensity of single entities in vitro or in living cells. It has been applied with aplomb to many different cellular processes and has significantly enlightened our understanding of the heterogeneity and complexity of biological systems. Recently, highresolution fluorescence microscopy has been brought to bear on telomeres, leading to new insights into telomere spatial organization and accessibility, and into the mechanistic nuances of telomere elongation. We provide a snapshot of some of these recent advances with a focus on mammalian systems, and show how threedimensional, time-lapse microscopy and single-molecule fluorescence shine a new light on the end of the chromosome.

\section{Keywords}

Fluorescence microscopy, telomeres, telomere elongation, telomere spatial organization, time-lapse microscopy, single-molecule fluorescence, chromosome

\section{Open Peer Review}

\section{Approval Status}

\section{2}

3

version 1

11 Dec 2015

Faculty Reviews are review articles written by the prestigious Members of Faculty Opinions. The articles are commissioned and peer reviewed before publication to ensure that the final, published version is comprehensive and accessible. The reviewers who approved the final version are listed with their names and affiliations.

\section{Raymund Wellinger, Université de}

Sherbrooke, Québec, Canada

2. Tracy Bryan, Children's Medical Research Institute, University of Sydney, Westmead, Australia

3. Michael Stone, University of California, Santa Cruz, USA

Any comments on the article can be found at the end of the article. 
Corresponding author: Lea Harrington (lea.harrington@umontreal.ca)

Competing interests: The authors declare that they have no competing interests.

Grant information: The author(s) declared that no grants were involved in supporting this work.

Copyright: $\odot 2015$ Benslimane $Y$ and Harrington L. This is an open access article distributed under the terms of the Creative Commons Attribution License, which permits unrestricted use, distribution, and reproduction in any medium, provided the original work is properly cited.

How to cite this article: Benslimane $Y$ and Harrington $L$. The lighthouse at the end of the chromosome* [version 1; peer review: 3 approved] F1000Research 2015, 4(F1000 Faculty Rev):1427 https://doi.org/10.12688/f1000research.6664.1

First published: 11 Dec 2015, 4(F1000 Faculty Rev):1427 https://doi.org/10.12688/f1000research.6664.1 


\section{Introduction}

Oskar Heimstädt, who built the first fluorescence microscope, ended his 1911 paper with the following perspective: "If and to what degree fluorescence microscopy will widen the possibilities of microscopic imaging only the future will show". More than a century later, fluorescence microscopy has proven transformative in our ability to illuminate almost all aspects of cellular biology. One of the more recent frontiers in fluorescence microscopy is the resolution of biological phenomena at the single molecule level, called single molecule fluorescence ${ }^{2}$. Biological processes have evolved to be inherently heterogeneous, transient and dynamic ${ }^{3}$, and therefore difficult to track. Single molecule microscopy often permits a birdseye view of ephemeral and complex mechanisms. This review will focus on selected recent advances in high-resolution microscopy including, but not limited to, single-molecule fluorescence microscopy, that have enlightened our understanding of chromosome ends and the enzyme that replenishes them.

Many organisms must contend with the vulnerability of linear chromosome ends to enzymes that degrade, rearrange, or incompletely replicate DNA. This susceptibility to breakage, and their distinct "knob-like" appearance under the light microscope, made them an early target of study by scientists such as Barbara McClintock and Hermann Müller ${ }^{4}$. We now appreciate that telomeres are a highly specialized nucleoprotein structure whose maintenance is critical to genome stability (Figure 1A-C) ${ }^{5,6}$. Replenishment of the G-rich sequences that comprise the telomeres is carried out by telomerase, whose core components are a reverse transcriptase and an integral RNA that provides the telomere template (Figure 1D) 7 .

\section{Zooming in on telomeres}

Fluorescence microscopy has revolutionized our ability to probe the length, location, and recombination of telomeres in vivo through the application of fluorescently labeled peptide nucleic acids that bind tightly and specifically to telomeric $\mathrm{DNA}^{8-10}$. These techniques have uncovered interesting distinctions in the three-dimensional (3D) localization of mammalian telomeres in normal cells versus cancer cells $^{11,12}$. Time-lapse microscopy has also revealed increased mobility of telomeres upon induction of a DNA break ${ }^{13}$ as well as unexpected long-range telomere associations in telomerase-negative cells after DNA breakage ${ }^{14}$. In the budding yeast Saccharomyces cerevisiae, fluorescent tagging of several components of telomerase have also provided considerable insight into the temporal and spatial dynamics of telomerase recruitment in living cells ${ }^{15-18}$.
A

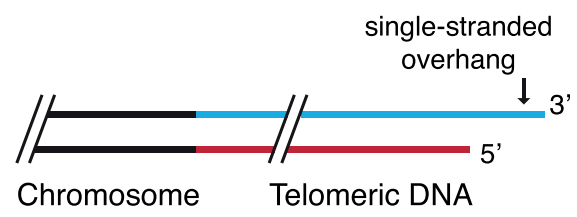

B

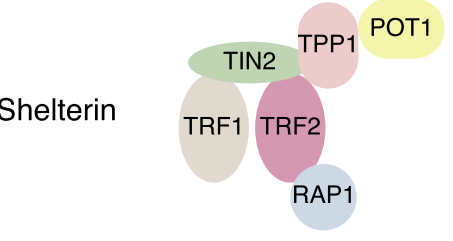

C

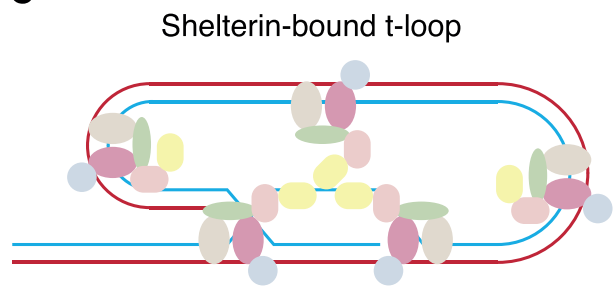

D
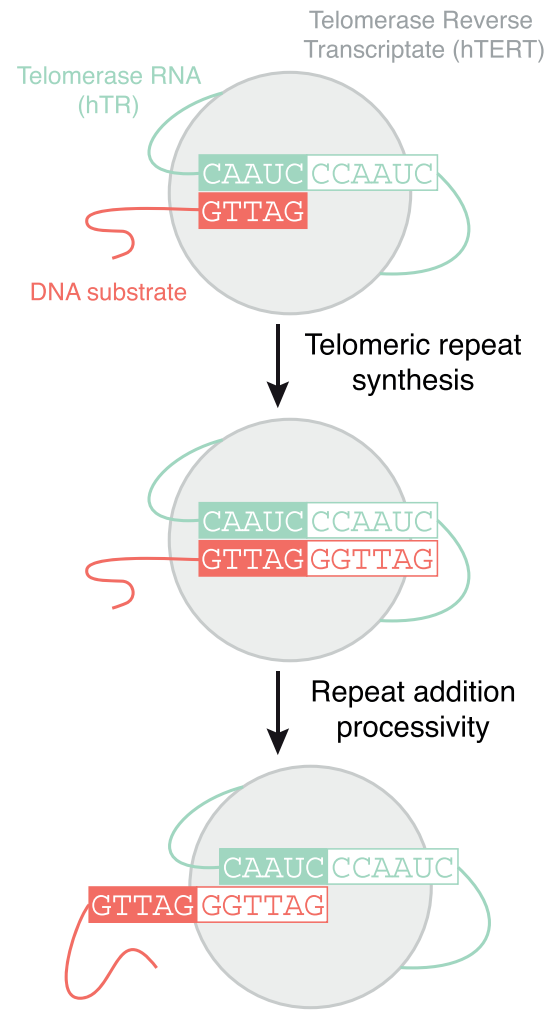

Figure 1. An overview of telomeres and telomerase. (A) In many organisms, chromosome ends terminate in a single-stranded, G-rich overhang preceded by up to several kilobase pairs of double-stranded G-rich DNA. (B) Telomeres are capped by a six-subunit complex called shelterin. (C) Shelterin (particularly TRF2) promotes the formation of a higher order telomeric loop (T-loop) structure that serves to mask telomeres from the deleterious fates associated with a free DNA end ${ }^{5,6}$. (D) The catalytic cycle of the core telomerase enzyme, comprised of a protein (TERT) and RNA (hTR) . 
Fluorescence microscopy is also being combined with other leadingedge technologies to directly target specific genomic regions, including the telomere. Using the CRISPR/Cas system in which Cas9 can be guided to specific genomic loci using a small RNA ${ }^{19}$, Chen and colleagues targeted an enhanced green fluorescent protein (EGFP)-tagged catalytically inert Cas9 specifically to telomeres ${ }^{20}$. Telomere-recruited Cas9 demonstrated a punctate pattern that spatially overlapped with that of the telomeric DNA binding protein, telomeric-repeat binding factor 2 (TRF2). Furthermore, EGFP intensity correlated linearly with telomere intensities obtained using fluorescence in situ hybridization (FISH) (Figure 2A) ${ }^{20}$. This method could also be employed to visualize Cas9 directed to a single genomic locus ${ }^{20}$. Technological advances such as these may soon permit the ability to explore the spatial and dynamic localization of telomeres and telomerase in living mammalian cells to a similar extent as has been explored in budding yeast.

The telomere terminus ends in a 3' G-rich overhang of variable length that can invade the upstream double-stranded telomeric DNA to form a structure called a T-loop ${ }^{21}$. Super-resolution microscopy, specifically stochastic optical reconstruction microscopy (STORM), has recently enabled an unprecedented visualization of T-loops that are crosslinked and purified from murine cells ${ }^{22}$ (Figure 1B,C). The loss of T-loops occurred specifically upon loss of the shelterin subunit TRF2, and not other shelterin components, which provides an elegant demonstration that it is the T-loop structure that protects ends from the deleterious molecular events observed when TRF2 is removed from telomeres ${ }^{22,23}$.

Telomeric DNA sequences can also form in vitro intra- or interparallel structures called G-quadruplexes, and evidence is accruing to suggest their existence at telomeres and at interstitial G-rich regions ${ }^{24}$. Single-molecule Förster resonance energy transfer (smFRET) has been applied to the molecular dynamics of G-quadruplex formation in vitro ${ }^{25-28}$ (Figure $2 \mathrm{~B}$ ). The smFRET approach has several advantages that permit a high-resolution view of G-quadruplex dynamics. Firstly, this technique can resolve different conformations using FRET signal intensities and Gaussian curve fitting ${ }^{29}$. Secondly, individual single-molecule traces reveal dynamic switching between states in real time. Hidden Markov modeling can then extract the dwell time of each molecule, which is a reflection of the stability of each state ${ }^{29}$. Applying smFRET to the analysis of shelterin binding to telomeric substrates in vitro, several groups have investigated the intricate relationship between G-quadruplexes and POT1/TPP1 (protection of telomere 1/Pot1-interacting protein TINT1-PTOPPIP1 $)^{30,31}$. Furthermore, this technique also revealed the binding and unfolding of G-quadruplexes by proteins such as RAD51, WRN, BLM, RecQ and RPA ${ }^{32-36}$. Recently, the use of smFRET combined with magnetic tweezers spectroscopy ${ }^{37}$ has been used to measure the thermodynamic properties of G-quadruplex folding ${ }^{38}$. These findings provide important insights into the dynamics of telomeric DNA structure in a more native nucleoprotein context.

\section{Shining a light on telomerase}

The telomerase reverse transcriptase, TERT, is able to synthesize new telomeric DNA, one nucleotide at a time, by virtue of an integral telomerase RNA that contains a short telomere-complementary sequence (Figure 1D). Although TERT shares several features in common with other viral reverse transcriptases, one unique aspect is its ability to repeatedly copy the same template for many cycles in an iterative process termed repeat addition processivity (RAP) ${ }^{39,40}$. Although much information has been gleaned using standard biochemical techniques regarding the complex DNA-protein, RNA-protein and protein-protein interactions that contribute to telomerase RAP (for a few current examples, see 41-46), it is only recently that single-molecule fluorescence has been brought to bear on the elongation properties of telomerase in vitro ${ }^{47}$. Hwang and colleagues immobilized immunopurified telomerase from cell extracts on a surface and employed a fluorescently labeled probe complementary to telomeric DNA to obtain a digital readout of telomerase activity in real time (Figure 2C). Their results suggested that active telomerase can exist in two dynamic states defined as an initial activation period followed by an extension period in which telomere elongation was visualized as a step-wise increase in fluorescence ${ }^{47}$. In addition, they found that TPP1-POT1 stimulated the elongation rate and overall product length ${ }^{47}$, consistent with previously described properties of TPP1-POT1. Although the nature of the fluorescent probe binding (which comprises the sequence $5^{\prime}$ CCCTAACCCTAACCC- $3^{\prime}$ ) precludes single base resolution, this technique promises to provide an unprecedented, single-molecule view of the intricacies of the telomerase elongation cycle.

In another smFRET approach, the distance between the region 5' of the RNA template of telomerase and a DNA substrate was followed during telomeric repeat synthesis (Figure 2D) ${ }^{48}$. Using different combinations of regular and chain-terminating nucleotides, information about the position of the DNA oligonucleotide substrate was registered at single-base pair resolution during elongation. While the substrate appears in a compact conformation after initial binding by telomerase, after a round of DNA synthesis the substrate realigns with the template via Watson-Crick base pair interactions. The aforementioned study by Parks and colleagues suggests that DNA dissociation and realignment is not the limiting step, and that an additional conformational adjustment is necessary after DNA: RNA repositioning to re-acquire a catalytically competent state ${ }^{48}$. This study illustrates the power of non-linear Gaussian curve fitting and hidden Markov modeling to extract the dwell time of the different FRET states from individual traces, which in turn permits a very precise dissection of the catalytic mechanism, albeit only over the short distances in which FRET can be observed.

smFRET has also been used to evince the real-time dynamics of folding of the pseudoknot domain with the telomerase RNA ${ }^{49-51}$. It has also been applied to examine the assembly and activity of the Tetrahymena thermophila telomerase $\mathrm{RNP}^{51-53}$ and, more recently, 

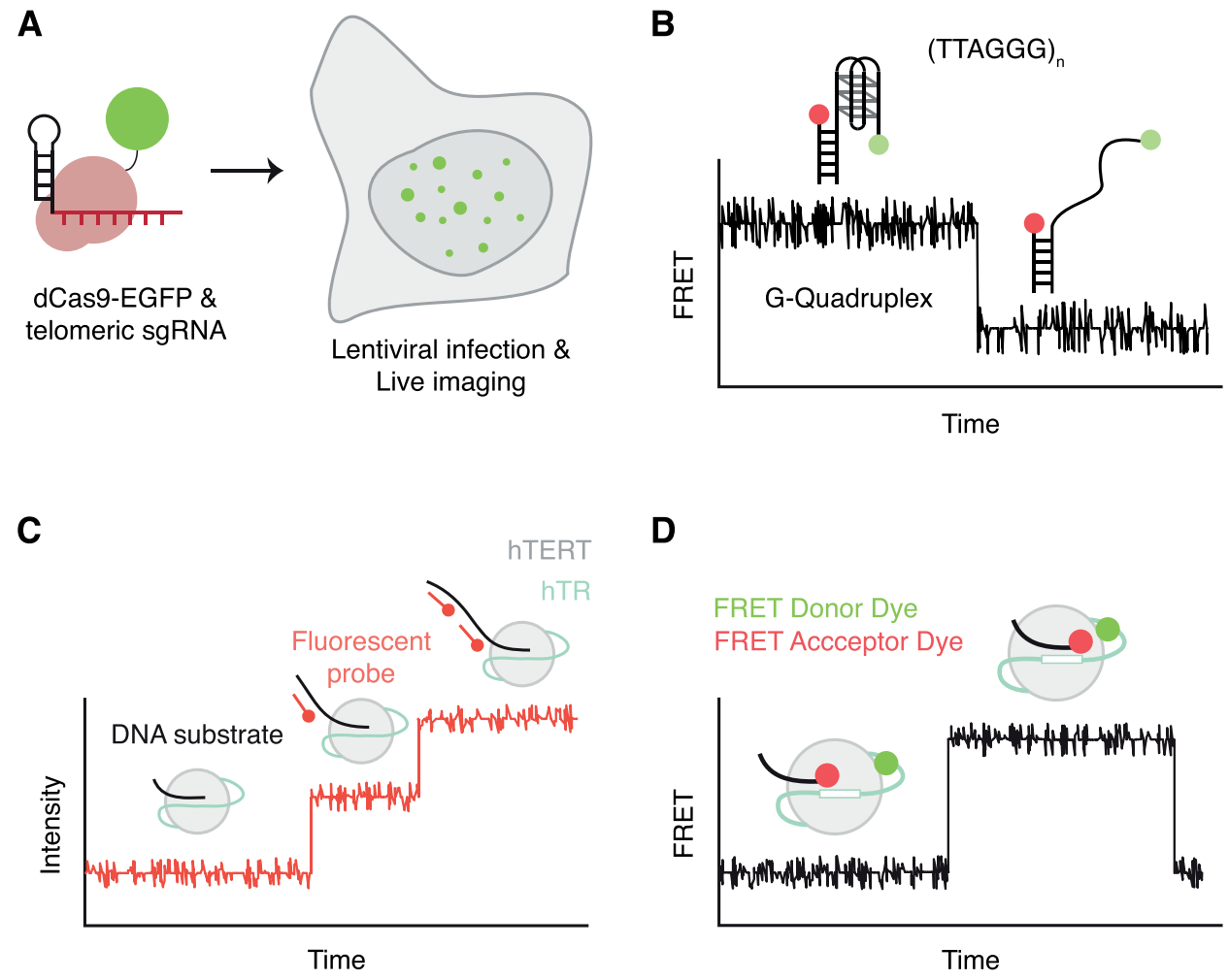

Figure 2. Selected recent advances in single-molecule microscopy that illuminate telomeres and telomerase. (A) The use of a fluorescently tagged Cas9 and a guide RNA specific to telomeres to measure telomere dynamics and length in live cells ${ }^{20}$. (B) The ability of single-molecule Förster resonance energy transfer (smFRET) to measure the dynamics of G-quadruplex folding 27,30-36,38. (C) The application of fluorescent probes complementary to telomeric substrates to measure the elongation properties of telomerase ${ }^{47}$. (D) The application of FRET to assess the intermolecular proximity of the DNA substrate and the RNA subunit of telomerase during telomere synthesis ${ }^{48}$.

the role of the N-terminal domain of T. thermophila TERT in the stabilization of short RNA:DNA hybrids during telomerase catalysis ${ }^{54}$. In addition to valuable insights into telomerase catalysis, these techniques might also permit a precise elucidation of the mechanism-ofaction of chemical modulators of telomerase activity, as well as an in vivo determination of human telomerase component stoichiometry, as was recently demonstrated for budding yeast telomerase ${ }^{18}$.

\section{Future perspectives}

In the year in which fluorescence microscopy was first described, Arthur Brisbane offered the sage advice: "Use a picture. It's worth a thousand words." ${ }^{55}$. We have reached a technological watershed in biology that will enable an unprecedented single-molecule and high-resolution view of the inner workings of many cellular machines. As we have illustrated here with but a few selected examples, fluorescence microscopy can be applied in many different ways to different problems, but key advances are the ability to dissect individual events instead of ensemble, population-based outputs, and to permit dynamic measurements in living cells, in real time. How far we have come from seeing telomeres as a cytogenetic "knob", and how far we have yet to come.

\section{Competing interests}

The authors declare that they have no competing interests.

\section{Grant information}

The author(s) declared that no grants were involved in supporting this work.

\section{Acknowledgments}

We thank Paul Maddox, Tracy Bryan, Michael Stone, and Raymund Wellinger for comments and constructive input on the review. 
1. Heimstadt O: Das Fluoreszenzmikroskop. Z Wiss Mikrosk. 1911; 28: 330-7.

2. Haustein E, Schwille P: Single-molecule spectroscopic methods. Curr Opin Struct Biol. 2004; 14(5): 531-40.

PubMed Abstract | Publisher Full Text

3. Pross A: On the emergence of biological complexity: life as a kinetic state of matter. Orig Life Evol Biosph. 2005; 35(2): 151-66.

PubMed Abstract | Publisher Full Text

4. Blackburn EH: A History of Telomere Biology. In: de Lange T, Lundblad V, Blackburn EH, editors. Telomeres. Cold Spring Harbor, NY: Cold Spring Harbor Laboratory Press. 2006; 1-19.

Reference Source

5. de Lange T: How shelterin solves the telomere end-protection problem. Cold Spring Harb Symp Quant Biol. 2010; 75: 167-77.

PubMed Abstract | Publisher Full Text

6. de Lange $T$ : Shelterin: the protein complex that shapes and safeguards human telomeres. Genes Dev. 2005; 19(18): 2100-10.

PubMed Abstract | Publisher Full Text

7. Autexier $C$, Lue NF: The structure and function of telomerase reverse transcriptase. Annu Rev Biochem. 2006; 75: 493-517. PubMed Abstract | Publisher Full Text

8. Aubert G, Hills M, Lansdorp PM: Telomere length measurement-caveats and a critical assessment of the available technologies and tools. Mutat Res. 2012; 730(1-2): 59-67.

PubMed Abstract | Publisher Full Text | Free Full Text

9. Williams ES, Cornforth MN, Goodwin EH, et al.: CO-FISH, COD-FISH, ReD-FISH, SKY-FISH. Methods Mol Biol. 2011; 735: 113-24.

PubMed Abstract | Publisher Full Text

10. Molenaar $\mathrm{C}$, Wiesmeijer $\mathrm{K}$, Verwoerd NP, et al:: Visualizing telomere dynamics in living mammalian cells using PNA probes. EMBO J. 2003; 22(24): 6631-41. PubMed Abstract | Publisher Full Text | Free Full Text

11. F Chuang TC, Moshir S, Garini $Y$, et al:: The three-dimensional organization of telomeres in the nucleus of mammalian cells. BMC Biol. 2004; $2: 12$. PubMed Abstract | Publisher Full Text | Free Full Text | F1000 Recommendation

12. F Lajoie V, Lemieux B, Sawan B, et al.: LMP1 mediates multinuclearity through downregulation of shelterin proteins and formation of telomeric aggregates. Blood. 2015; 125(13): 2101-10.

PubMed Abstract | Publisher Full Text | Free Full Text | F1000 Recommendation

13. F Dimitrova N, Chen YC, Spector DL, et al:: 53BP1 promotes non-homologous end joining of telomeres by increasing chromatin mobility. Nature. 2008; 456(7221): 524-8.

PubMed Abstract | Publisher Full Text | Free Full Text | F1000 Recommendation

14. F Cho NW, Dilley RL, Lampson MA, et al:: Interchromosomal homology searches drive directional ALT telomere movement and synapsis. Cell. 2014; 159(1): 108-21.

PubMed Abstract | Publisher Full Text | Free Full Text | F1000 Recommendation

15. F Cusanelli E, Romero CA, Chartrand P: Telomeric noncoding RNA TERRA is induced by telomere shortening to nucleate telomerase molecules at short telomeres. Mol Cell. 2013; 51(6): 780-91.

PubMed Abstract | Publisher Full Text | F1000 Recommendation

16. $\mathrm{F}$ Gallardo $\mathrm{F}$, Laterreur $\mathrm{N}$, Cusanelli $\mathrm{E}$, et al.: Live cell imaging of telomerase RNA dynamics reveals cell cycle-dependent clustering of telomerase at elongating telomeres. Mol Cell. 2011; 44(5): 819-27.

PubMed Abstract | Publisher Full Text | F1000 Recommendation

17. F Gallardo F, Olivier C, Dandjinou AT, et al.: TLC1 RNA nucleo-cytoplasmic trafficking links telomerase biogenesis to its recruitment to telomeres. $E M B O$ J. 2008; 27(5): 748-57.

PubMed Abstract | Publisher Full Text | Free Full Text | F1000 Recommendation

18. F Bajon E, Laterreur N, Wellinger RJ: A Single Templating RNA in Yeast Telomerase. Cell Rep. 2015; 12(3): 441-8.

PubMed Abstract | Publisher Full Text | F1000 Recommendation

19. Sander JD, Joung JK: CRISPR-Cas systems for editing, regulating and targeting genomes. Nat Biotechnol. 2014; 32(4): 347-55.

PubMed Abstract | Publisher Full Text | Free Full Text

20. F Chen B, Gilbert LA, Cimini BA, et al:: Dynamic imaging of genomic loci in living human cells by an optimized CRISPR/Cas system. Cell. 2013; 155(7): 1479-91.

PubMed Abstract | Publisher Full Text | Free Full Text | F1000 Recommendation

21. Griffith JD, Comeau L, Rosenfield S, et al.: Mammalian telomeres end in a large duplex loop. Cell. 1999; 97(4): 503-14. PubMed Abstract | Publisher Full Tex

22. F Doksani $Y$, Wu JY, de Lange $T$, et al:: Super-resolution fluorescence imaging of telomeres reveals TRF2-dependent T-loop formation. Cell. 2013; 155(2): 345-56.

PubMed Abstract | Publisher Full Text | Free Full Text | F1000 Recommendation

23. Sfeir $\mathrm{A}$, de Lange $\mathrm{T}$ : Removal of shelterin reveals the telomere end-protection problem. Science. 2012; 336(6081): 593-7.

PubMed Abstract | Publisher Full Text | Free Full Text

24. Murat $P$, Balasubramanian S: Existence and consequences of G-quadruplex structures in DNA. Curr Opin Genet Dev. 2014; 25: 22-9.

PubMed Abstract | Publisher Full Text
25. Ha T: Single-molecule fluorescence resonance energy transfer. Methods. 2001; 25(1): 78-86

PubMed Abstract | Publisher Full Text

26. Okumus B, Ha T: Real-time observation of G-quadruplex dynamics using single-molecule FRET microscopy. Methods Mol Biol. 2010; 608: 81-96. PubMed Abstract | Publisher Full Text

27. $\mathrm{F}$ Long $\mathrm{X}$, Stone MD: Kinetic partitioning modulates human telomere DNA G-quadruplex structural polymorphism. PLoS One. 2013; 8(12): e83420. PubMed Abstract | Publisher Full Text | Free Full Text | F1000 Recommendation

28. F Dhakal S, Cui $Y$, Koirala D, et al:: Structural and mechanical properties of individual human telomeric G-quadruplexes in molecularly crowded solutions. Nucleic Acids Res. 2013; 41(6): 3915-23.

PubMed Abstract | Publisher Full Text | Free Full Text | F1000 Recommendation

29. Blanco M, Walter NG: Analysis of complex single-molecule FRET time trajectories. Methods Enzymol. 2010; 472: 153-78. PubMed Abstract | Publisher Full Text | Free Full Text

30. $\mathrm{F}$ Hwang $\mathrm{H}$, Buncher $\mathrm{N}$, Opresko PL, et al:: POT1-TPP1 regulates telomeric overhang structural dynamics. Structure. 2012; 20(11): 1872-80. PubMed Abstract | Publisher Full Text | Free Full Text | F1000 Recommendation

31. F Ray S, Bandaria JN, Qureshi MH, et al:: G-quadruplex formation in telomeres enhances POT1/TPP1 protection against RPA binding. Proc Nat Acad Sci U S A. 2014; 111(8): 2990-5.

PubMed Abstract | Publisher Full Text | Free Full Text | F1000 Recommendation

32. $\mathrm{F}$ Hwang $\mathrm{H}$, Kreig A, Calvert $\mathrm{J}$, et al:: Telomeric overhang length determines structural dynamics and accessibility to telomerase and ALT-associated proteins. Structure. 2014; 22(6): 842-53.

PubMed Abstract | Publisher Full Text | Free Full Text | F1000 Recommendation

33. F Budhathoki JB, Ray S, Urban V, et al.: RecQ-core of BLM unfolds telomeric G-quadruplex in the absence of ATP. Nucleic Acids Res. 2014; 42(18): 11528-45. PubMed Abstract | Publisher Full Text | Free Full Text | F1000 Recommendation

34. F Budhathoki JB, Stafford EJ, Yodh JG, et al:: ATP-dependent G-quadruplex unfolding by Bloom helicase exhibits low processivity. Nucleic Acids Res. 2015 43(12): 5961-70.

PubMed Abstract | Publisher Full Text | Free Full Text | F1000 Recommendation

35. F Qureshi MH, Ray S, Sewell AL, et al.: Replication protein A unfolds G-quadruplex structures with varying degrees of efficiency. J Phys Chem $B$. 2012; 116(19): 5588-94.

PubMed Abstract | Publisher Full Text | Free Full Text | F1000 Recommendation

36. F Ray S, Qureshi MH, Malcolm DW, et al:: RPA-mediated unfolding of systematically varying G-quadruplex structures. Biophys J. 2013; 104(10) 2235-45.

PubMed Abstract | Publisher Full Text | Free Full Text | F1000 Recommendation

37. Woodside MT, Block SM: Reconstructing folding energy landscapes by single-molecule force spectroscopy. Annu Rev Biophys. 2014; 43: 19-39. PublMed Abstract | Publisher Full Text | Free Full Text

38. F Long X, Parks JW, Bagshaw CR, et al:: Mechanical unfolding of human telomere G-quadruplex DNA probed by integrated fluorescence and magnetic tweezers spectroscopy. Nucleic Acids Res. 2013; 41(4): 2746-55.

PubMed Abstract | Publisher Full Text | Free Full Text | F1000 Recommendation

39. Greider CW: Telomerase is processive. Mol Cell Biol. 1991; 11(9): 4572-80. PubMed Abstract | Publisher Full Text | Free Full Text

40. Peng Y, Mian IS, Lue NF: Analysis of telomerase processivity: mechanistic similarity to HIV-1 reverse transcriptase and role in telomere maintenance. Mol Cell. 2001; 7(6): 1201-11.

PubMed Abstract | Publisher Full Text

41. Berman AJ, Akiyama BM, Stone MD, et al:: The RNA accordion model for template positioning by telomerase RNA during telomeric DNA synthesis. Nat Struct Mol Biol. 2011; 18(12): 1371-5.

PubMed Abstract | Publisher Full Text | Free Full Text

42. Qi X, Xie M, Brown AF, et al.: RNA/DNA hybrid binding affinity determines telomerase template-translocation efficiency. EMBO J. 2012; 31(1): 150-61. PubMed Abstract | Publisher Full Text | Free Full Text

43. Steczkiewicz K, Zimmermann MT, Kurcinski M, et al: Human telomerase model shows the role of the TEN domain in advancing the double helix for the next polymerization step. Proc Natl Acad Sci U S A. 2011; 108(23): 9443-8. PubMed Abstract | Publisher Full Text | Free Full Text

44. Tomlinson CG, Moye AL, Holien JK, et al:: Two-step mechanism involving active-site conformational changes regulates human telomerase DNA binding. Biochem J. 2015; 465(2): 347-57. PubMed Abstract | Publisher Full Tex

45. Wu RA, Collins K: Human telomerase specialization for repeat synthesis by unique handling of primer-template duplex. EMBO J. 2014; 33(8): 921-35. PubMed Abstract | Publisher Full Text | Free Full Text

46. Dalby $A B$, Hofr $C$, Cech TR: Contributions of the TEL-patch amino acid cluster on TPP1 to telomeric DNA synthesis by human telomerase. $J$ Mol Biol. 2015; 427(6 Pt B): 1291-303

PubMed Abstract | Publisher Full Text | Free Full Text

47. $\mathrm{F}$ Hwang $\mathrm{H}$, Opresko $\mathrm{P}$, Myong S: Single-molecule real-time detection of telomerase extension activity. Sci Rep. 2014; 4: 6391.

PubMed Abstract | Publisher Full Text | Free Full Text | F1000 Recommendation 
48. F Parks JW, Stone MD: Coordinated DNA dynamics during the human telomerase catalytic cycle. Nat Commun. 2014; 5: 4146.

PubMed Abstract | Publisher Full Text | Free Full Text | F1000 Recommendation

49. F Holmstrom ED, Nesbitt DJ: Single-molecule fluorescence resonance energy transfer studies of the human telomerase RNA pseudoknot: temperature/urea-dependent folding kinetics and thermodynamics. J Phys Chem B. 2014; 118(14): 3853-63.

PubMed Abstract | Publisher Full Text | Free Full Text | F1000 Recommendation

50. F Hengesbach M, Kim NK, Feigon J, et al:: Single-molecule FRET reveals the folding dynamics of the human telomerase RNA pseudoknot domain. Angew Chem Int Ed Engl. 2012; 51(24): 5876-9.

PubMed Abstract | Publisher Full Text | Free Full Text | F1000 Recommendation

51. F Mihalusova M, Wu JY, Zhuang X: Functional importance of telomerase pseudoknot revealed by single-molecule analysis. Proc Natl Acad Sci U S A.
2011; 108(51): 20339-44

PubMed Abstract | Publisher Full Text | Free Full Text | F1000 Recommendation

52. F Stone MD, Mihalusova M, O'connor CM, et al.: Stepwise protein-mediated RNA folding directs assembly of telomerase ribonucleoprotein. Nature. 2007; 446(7134): 458-61.

PubMed Abstract | Publisher Full Text | Free Full Text | F1000 Recommendation

53. F Wu JY, Stone MD, Zhuang X: A single-molecule assay for telomerase structure-function analysis. Nucleic Acids Res. 2010; 38(3): e16.

PubMed Abstract | Publisher Full Text | Free Full Text | F1000 Recommendation

54. F Akiyama BM, Parks JW, Stone MD: The telomerase essential N-terminal domain promotes DNA synthesis by stabilizing short RNA-DNA hybrids. Nucleic Acids Res. 2015; 43(11): 5537-49.

PubMed Abstract | Publisher Full Text | Free Full Text | F1000 Recommendation

55. Brisbane A: Speakers Give Sound Advice. Syracuse Post Standard. 1911. 


\section{Open Peer Review}

\section{Current Peer Review Status:}

\section{Editorial Note on the Review Process}

Faculty Reviews are review articles written by the prestigious Members of Faculty Opinions. The articles are commissioned and peer reviewed before publication to ensure that the final, published version is comprehensive and accessible. The reviewers who approved the final version are listed with their names and affiliations.

\section{The reviewers who approved this article are:}

\section{Version 1}

\section{Michael Stone}

Department of Chemistry and Biochemistry, University of California, Santa Cruz, CA, USA

Competing Interests: No competing interests were disclosed.

\section{Tracy Bryan}

Children's Medical Research Institute, University of Sydney, Westmead, NSW, Australia

Competing Interests: No competing interests were disclosed.

\section{Raymund Wellinger}

Department of Microbiology and Infectious Diseases, Faculty of Medicine, Université de Sherbrooke, Québec, Canada

Competing Interests: No competing interests were disclosed.

The benefits of publishing with F1000Research:

- Your article is published within days, with no editorial bias

- You can publish traditional articles, null/negative results, case reports, data notes and more

- The peer review process is transparent and collaborative

- Your article is indexed in PubMed after passing peer review

- Dedicated customer support at every stage

For pre-submission enquiries, contact research@f1000.com 